\title{
Accounting
}

\section{Leverage, capital and profitability of the banks: Evidence from Saudi Arabia}

\author{
Abdul Rahman Shaik ${ }^{a^{*}}$ and Raj Bahadur Sharma ${ }^{a}$
}

\begin{tabular}{l}
${ }^{a}$ Assistant Professor, College of Business \\
\hline C H R O N I C L E \\
\hline Article history: \\
Received: November 30, 2020 \\
Received in revised format: \\
April 32021 \\
Accepted: April 4, 2021 \\
Available online: \\
April 4, 2021 \\
\hline Keywords: \\
Debt \\
Equity \\
Capital \\
Return on Assets \\
Return on Equity \\
Earnings per Share \\
Tier 1 capital \\
Total Debt \\
Banks \\
Saudi Arabia \\
\hline
\end{tabular}

\section{Introduction}

\section{A B S T R A C T}

The study examines the effect of leverage and capital on the profitability of selected Saudi Arabian Banks during the period 2014 and 2019. The banks have been selected based upon their size in terms of total assets. The profitability elements, such as Earnings per Share (EPS), Return on Assets (ROA), and Return on Equity (ROE) are the dependent variables; Total Debt Ratio (TDR), Tier 1 Capital Ratio (Tier 1 CAP), and Debt to Equity Ratio (DE) are the independent variables, and firm size is the control variable. The study estimates a pooled regression analysis to analyze the effect of these variables. The results of the study show that there is a positive relationship between the different profitability variables and Debt to Equity Ratio. The Total Debt Ratio is having positive association with ROA and ROE, and has an insignificant negative relationship with the EPS, and the Tier 1 capital ratio is having positive association with ROA and ROE, and has an insignificant relationship with the EPS.

The concept of leverage and capital used by the company plays a significant role in equity mix decisions. Past decades have seen extensively the examination of association between equity mix and firm performance. The suggestion given by Modigliani and Miller (1958), that the debt-equity mix does not have any relation with the firm value, hence of no concern to the financial managers have no evidence in reality (Ahmed et al., 2012; Bagais \& Aljaaidi, 2020). The organizations in today's world treat debt-equity mix as one of the significant financing decisions to enhance the value of the firm. Therefore, a strategic firm should maintain an optimal mix of debt and equity in asset financing. Nevertheless, the theory of Modigliani and Miller (1958) has provided evidence of capital structure irrelevance with absence of taxes and other costs; the other theory of including corporate taxes was introduced, suggesting the use of more debt in the capital structure to enhance the firm value (Modigliani \& Miller, 1963). There are other theories explaining the debt-equity mix, such as the agency cost theory, the trade-off theory, and the pecking order theory. The extent of accomplishing a financial goal by a firm is termed as financial performance, where a firm measures its operations in monetary terms over a period. Increase in firms' size brings in more cash and economies to scale leading to profitability. The concept of financial performance is significant in terms of explaining the ability of firms in meeting the demands of stakeholders.

* Corresponding author

E-mail address: a.shaik@psau.edu.sa (A. R. Shaik) 
The banking sector in Saudi Arabia is considered to be playing a key role in attaining the Kingdoms' Vision 2030. Different stakeholders treat the banks as important entities, because of their soundness as a going concern including the Saudi Arabian Monetary Authority (SAMA), the central bank of Saudi Arabia. The capital of a bank is significant for their existence and success. The developed economies set up a Basel committee to regulate banks' capital through capital regulation framework. Currently, the banks in Saudi Arabia are regulated as per the Basel III norms. The current regulation of the SAMA limits the banks of Saudi Arabia to lend 15 percent of their Tier 1 capital to a single consumer against the previous regulation of 25 percent. Moreover, the SAMA regulations in other aspects have affected the credit strategy of banks as a whole. Nevertheless, there were challenges in different aspects for the Saudi Arabian economy; the banking sector was resilient throughout the low growth period. The performance reported by the Saudi banks during the year 2019 was 13 percent higher compared to the year 2018. Besides, the banking sector of Saudi Arabia faces challenges, such as growing loan books, increase in cost of lending, competition from digital payments, etc. In light of the above-discussed factors, such as the debt, capital and profitability of banks, and the performance of Saudi banks, it becomes significant to study the effect of these factors on their financial performance.

\section{Literature review}

Ebiringa and Ezeji (2012) studied the effect of leverage financing on company performance of Nigerian banking industry. The study concluded that the financial leverage leads the banking industry to establish strategic balance with associated financing and returns to equity. Ho and Hsu (2010) examined the relationship between financial structures and risky investment in Tiawan's banking sector, and found that risky investments and leverages are positively related. GWEYI and Karanja (2014) investigated the effect of financial leverage on financial performance of deposit in Kenya and reported a perfect positive correlation between debt equity ratio with return on equity and profit after tax. Obradovich and Gill (2013) studied the impact of corporate governance and financial leverage. The outcomes of the study show that larger board size negatively impacts the value of firms. Akhtar et al. (2012) measured the relationship between financial leverage and financial performance of Karachi Stock Exchange listed companies, and demonstrated that the financial leverage has a positive relationship with financial performance. Zeitun and Saleh (2015) investigate the effect of financial leverage on the firm's financial performance in Gulf Cooperation Council (GCC) countries. They indicate that firm's leverage is a significant determinant of firm's performance in GCC countries.

Mukras (2015) studied the relationship between financial leverage and financial performance of listed companies in Kenya, and found strong evidence that financial leverage has a negative but insignificant effect on Return on Equity. Al-Tally (2014) examined the effect of the debt and equity mix (financial leverage) on firm's performance and reported that in the long term, lower leverage levels tend to lead to higher profit margin and returns on both assets and equity in the absence of acute economic downturns. Daryanto et al. (2018) studied the impact of financial liquidity and leverage on the financial performance of Indonesian real estate companies, and reported that current ratio and debt assets ratio had negative relationships with Return on Assets. Ahmad (2016) examined the relationship between profitability and liquidity in the standard chartered bank of Pakistan. The study found that there is a weak positive relationship between liquidity and profitability. Almajali et al. (2012) studied the factors that mostly affect financial performance of Jordanian Insurance Companies. The study considered 25 insurance companies and data was analyzed by using multiple regressions, and concluded that leverage, liquidity, Size, management competence index have positive statistical effect on financial performance of selected insurance companies.

Javed et al. (2015) examined the effect of financial leverage on efficiency of firms in Pakistan. The study considered 154 textile firms in Pakistan over the period of 2006 to 2011. The results indicated that leverage has a negative association with the efficiency of textile firms, and the financial leverage is negatively associated with return on assets and equity. John et al. (2015) examined the relationship between financial leverage and financial performance in the context of Nigerian hospital industry. They found that the existence of a positive and statistically significant relationship between leverage and financial performance in the Nigerian hospital industry. Afolabi et al. (2019) examined the relationship between leverage and financial performance of Nigerian Firms, and reported a positive and significant effect between leverage and Return on Capital Employed (ROCE). ABUBAKAR (2017) analyzed the effect of financial leverage on the financial performance of Industrial Goods firms in Nigeria during 2005-2016. The study found that short-term debt ratio and total debt ratio have no significant effect on the firms' financial performance while total debt ratio has significant negative effect on financial performance on return on equity (ROE).

Gill et al. (2012) examined the influence of financial leverage of small business firms in India. It was found that small business growth, small business performance, total assets, sales, tax and family size have a positive influence on the financial leverage of small business firms in India. Singh et al. (2016) attempt to investigate the impact of financial leverage on firm's financial performance and firm's valuation, and found that Return on Total Assets and Economic Value Added are the indicators of firm's profitability and the leverage has a significant negative impact on firm's performance indicator EVA and ROA. Dalci (2018) explored the influence of financial leverage on profitability of manufacturing firms in China. The result reveals that the impact of financial leverage on profitability could be attributed to tax shield, whereas the negative impact might be because of 
bankruptcy cost, financial distress, and problems and information asymmetry. Barakat (2014) investigated the effect of financial structure, financial leverage and profitability on a company's value. The study concluded that there is a statistically significant direct relationship between return on equity and capital structure with stock market price. However, there is a weak and inverse relationship between financial leverage and stock. Ilyukhin (2015) studied the relationship between financial leverage and firm performance. The study considered a large sample of Russian joint stock companies over the period of 2004-2013 and showed the negative performance on Russian firm's by financial leverage.

Wabwile et al.(2014) analyzed the performance of commercial banks listed on NSE by using Return on Assets (ROA), Return on Capital employed (ROCE), Earning per share (EPS), dividend yield (DY) and value of the firm price book value (PBV). They found that there is a negative correlation between debt assets ratio and ROAC and ROCEC respectively, whereas, there is positive correlation between debt assets ratio and EPS. Kumar (2014) studied the relationship between leverage and profitability in Bata India Ltd. The study considered seven years 2005-2012 financial data of the company, and reported that there is the degree of operating leverage is statistically significant positive correlation with return on investment (ROI) whereas degree of financial leverage has positive correlation with ROI. Ahmad et al. (2015) examined the relationship between financial leverage and profitability of the cement industry in Pakistan, and found that financial leverage has a significant negative impact on profitability. Ali (2020) investigated the effect of operating, financial and combined leverages on the financial performance of food and fertilizer companies listed under Pakistan Stock market using correlation analysis and regression. The result of the study reveals that the degree of financial leverage and combined leverage significantly impact on return on assets (ROA) whereas, there is impact on financial performance measured by ROA.

Mangalam and Govindasamy (2010) has determined the leverage effect on profitability by taking over cement companies from India. The results show the relationship between the debt-to-equity ratio and the earnings per share and the effectiveness of the company in obtaining financing using the debt. These results showed that leverage had a positive impact on the profitability of the firm and that growth and leverage were also positive. Ujah and Brusa (2013) examined the extent to which firms managed their earnings and were affected from financial leverage and cash flow management, and found the relationship among leverage, instability in cash flow and earning management. Pratheepkanth (2011) studied the association between capital structure and financial performance of companies in Sri Lanka, and reported that there is a negative relationship between the capital structure and financial performance of firms. Morellec, E. (2004), the study analyzed the impact of managerial discretion and corporate control mechanisms on leverage and firm value. The contingent claims model shows that manager and shareholders conflicts can explain the low debt level observed in practice. It also examines the impact of these conflicts on the cross-sectional variation in capital structure.

Adesina et al. (2015) studied the impact of post-consolidation capital structure on the financial performance of Banks in Nigeria and concluded that capital structure has a significant positive relationship with the financial performance of banks. Bauar (2004) has studied the effect of the following on the capital structure: size, profitability, tangibility, growth opportunities, tax, non-debt tax shields, volatility, and industry classification. He concluded that leverage was positively correlated with size, while leverage was negatively correlated with profitability.

\section{Research methodology}

We examine the effect of leverage on the financial performance of selected banks in the Kingdom of Saudi Arabia starting from 2014 and ending 2019. We have selected five banks basing upon their total assets (SIZE), and data availability. We have collected the financial data from the annual reports of banks, and calculated different ratios used as study variables. We provide basic analysis of predictable and unpredictable variables through descriptive statistics, and measure the strength of these variables with the help of correlation analysis. Further, we adopt pooled regression for empirical analysis.

\subsection{Predictable and Unpredictable Variables}

We introduce Earnings per Share (EPS), Return on Assets (ROA), and Return on Equity (ROE) as the predictable variables; Total Debt Ratio (TDR), Tier 1 Capital Ratio (Tier 1 CAP), and Debt-Equity ratio (DE) as unpredictable variables, and firm size as a controllable variable. The different types of variables with their definitions are given in Table 1.

\section{Hypotheses}

$\mathrm{H}_{01}$ : There is a relationship between the Earnings per Share (EPS) and leverage and capital.

$\mathrm{H}_{02}$ : There is a relationship between Return on Assets (ROA) and leverage and capital.

$\mathrm{H}_{03}$ : There is a relationship between Return on Equity (ROE) and leverage and capital. 


\section{Table 1}

Definition of Study Variables

\begin{tabular}{lll}
\hline \multicolumn{1}{c}{ Variables } & \multicolumn{1}{c}{ Definition } \\
\hline Return on Assets (ROA) & Net Income before Tax /Total Assets & \\
Return on Equity (ROE) & Net Income before Tax and Preference Dividend/Total Shareholders' Equity \\
Earnings Per Share (EPS) & Net Income before Tax and Preference Dividend/Number of Common Shares Outstanding \\
Firm Size (Size) & Log of Total Assets & -- \\
Debt-Equity (DE) & Total Debt/Total Equity \\
Total Debt Ratio (TDR) & Total Debt/Total Assets \\
Tier 1 Capital Ratio & Tier 1 Capital/Total Assets \\
\hline
\end{tabular}

\subsection{Estimated Regression}

To study the effect of leverage on the financial performance of banks, we estimate a regression with pooled data. This regression estimates cross-sectional data with time-series, and is useful over individual methods of cross-section or time-series (Raheman \& Nasr, 2007; Rahman \& Sharma, 2020). The pooled regression model is as follows:

$$
\begin{aligned}
& E P S_{i, t}=\alpha_{0}+\beta_{1} D E_{i, t}+\beta_{2} S I Z E_{i, t}+\varepsilon_{i, t} \\
& E P S_{i, t}=\alpha_{0}+\beta_{1} D E_{i, t}+\beta_{2} T D R_{i, t}+\beta_{3} S I Z E_{i, t}+\varepsilon_{i, t} \\
& E P S_{i, t}=\alpha_{0}+\beta_{1} D E_{i, t}+\beta_{2} T D R_{i, t}+\beta_{3} \text { TierlCAP } P_{i, t}+\beta_{4} S_{I Z E_{i, t}}+\varepsilon_{i, t} \\
& R O A_{i, t}=\alpha_{0}+\beta_{1} D E_{i, t}+\beta_{2} S I Z E_{i, t}+\varepsilon_{i, t} \\
& R O A_{i, t}=\alpha_{0}+\beta_{1} D E_{i, t}+\beta_{2} T D R_{i, t}+\beta_{3} S_{I Z E_{i, t}}+\varepsilon_{i, t} \\
& R O A_{i, t}=\alpha_{0}+\beta_{1} D E_{i, t}+\beta_{2} T_{D R} R_{i, t}+\beta_{3} \operatorname{TierlCAP}_{i, t}+\beta_{4} \operatorname{SIZE}_{i, t}+\varepsilon_{i, t} \\
& R O E_{i, t}=\alpha_{0}+\beta_{1} D E_{i, t}+\beta_{2} S I Z E_{i, t}+\varepsilon_{i, t} \\
& R O E_{i, t}=\alpha_{0}+\beta_{1} D E_{i, t}+\beta_{2} T D R_{i, t}+\beta_{3} S I Z E_{i, t}+\varepsilon_{i, t} \\
& R O E_{i, t}=\alpha_{0}+\beta_{1} D E_{i, t}+\beta_{2} T D R_{i, t}+\beta_{3} \operatorname{TierlCAP} P_{i, t}+\beta_{4} S I Z E_{i, t}+\varepsilon_{i, t}
\end{aligned}
$$

wherein $\alpha_{0}$ represents the intercept, $\beta_{1}$ is the coefficient of $D E$ as per Eqs. (1-9), $\beta_{2}, \beta_{3}$ and $\beta_{4}$ are the coefficients of unpredictable and control variables in different equations.

\subsection{Empirical Results}

\begin{tabular}{|c|c|c|c|c|}
\hline Variable & Mean & Standard Deviation & Minimum & Maximum \\
\hline $\mathrm{ROA}$ & 1.19 & 1.07 & 1.03 & 2.66 \\
\hline ROE & 0.69 & 0.77 & 0.62 & 2.48 \\
\hline EPS & 1.56 & 1.55 & 1.03 & 5.61 \\
\hline $\mathrm{DE}$ & 2.85 & 3.04 & 3.10 & 9.96 \\
\hline TDR & 5.36 & 4.03 & 8.04 & 8.92 \\
\hline Tier $1 \mathrm{CR}$ & 2.63 & 2.59 & 2.90 & 6.12 \\
\hline SIZE & 0.92 & 0.97 & 1.90 & 1.99 \\
\hline $\mathrm{N}$ & \multicolumn{4}{|c|}{05} \\
\hline
\end{tabular}

Table 2 reports the descriptive statistics of different variables employed in the current study. The results show that the mean of financial performance variables ranges from 0.69 to 1.56 , which indicates a poor performance of Saudi banks during the study period. Further, the mean of leverage variables ranges from 2.85 to 5.36, which indicates that the Saudi banks does not have higher level of debt in their capital structure, and the mean of Tier 1 capital is 2.63 , which is nearly half of the ratio (a ratio of 6) suggested by the Basel III committee. The standard deviation of predictable and unpredictable variables ranges from 0.77 to 4.03 .

\section{Table 2}

Summary of some descriptive statistics

Table 3 reports the relationship between predictable and unpredictable variables. The results show a positive association between the variables of banks' profitability, such as ROA, ROE and EPS and DE, TDR, Tier 1 Capital.

\section{Table 3}

Summary of the correlation analysis

\begin{tabular}{lccccc}
\hline Variable & ROA & ROE & EPS & DE & TDR \\
\hline ROA & 1.0000 & & & & \\
ROE & 0.4304 & 1.0000 & & & \\
EPS & 0.3521 & 0.5262 & 1.0000 & & \\
DE & 0.4083 & 0.5855 & 0.5543 & 1.0000 & 1.0000 \\
TDR & 0.4064 & 0.3208 & 0.3063 & 0.5172 & 0.4237 \\
Tier 1 CR & 0.3878 & 0.4576 & 0.2950 & 0.3701 & 0.4462 \\
SIZE & 0.3970 & 0.5116 & 0.5278 & 0.5475 & 1.0000 \\
\hline
\end{tabular}


A. R. Shaik and R. B. Sharma /Accounting 7 (2021)

We report the results of pooled regression in this subsection estimated under different models. Table 4 reports the results of Models 1, 2 and 3 where EPS is a predictable variable. The result shows that the unpredictable variable of leverage, DE is positive and significant at the $1 \%$ level of significance in all the three models. Similarly, the control variable SIZE is also positive and significant at the $1 \%$ level of significance in all the three models. Further, the unpredictable variable TDR in model 2 is negative but insignificant in models 2 and 3. Moreover, the variable of capital, Tier 1 CAP in model 3 is positive and insignificant. The adjusted $\mathrm{R}^{2}$ of models 1,2 and 3 is $0.37,0.37$ and 0.36 , which shows that $37 \%$ of the variation in EPS on an average is explained by different unpredictable variables in different models. Furthermore, the F-statistic of all the models is significant at the $1 \%$ level of significance showing fitness of the model, and there is no multicollinearity among the unpredictable variables as the VIF is less than 2.

\section{Table 4}

The results of regression analysis

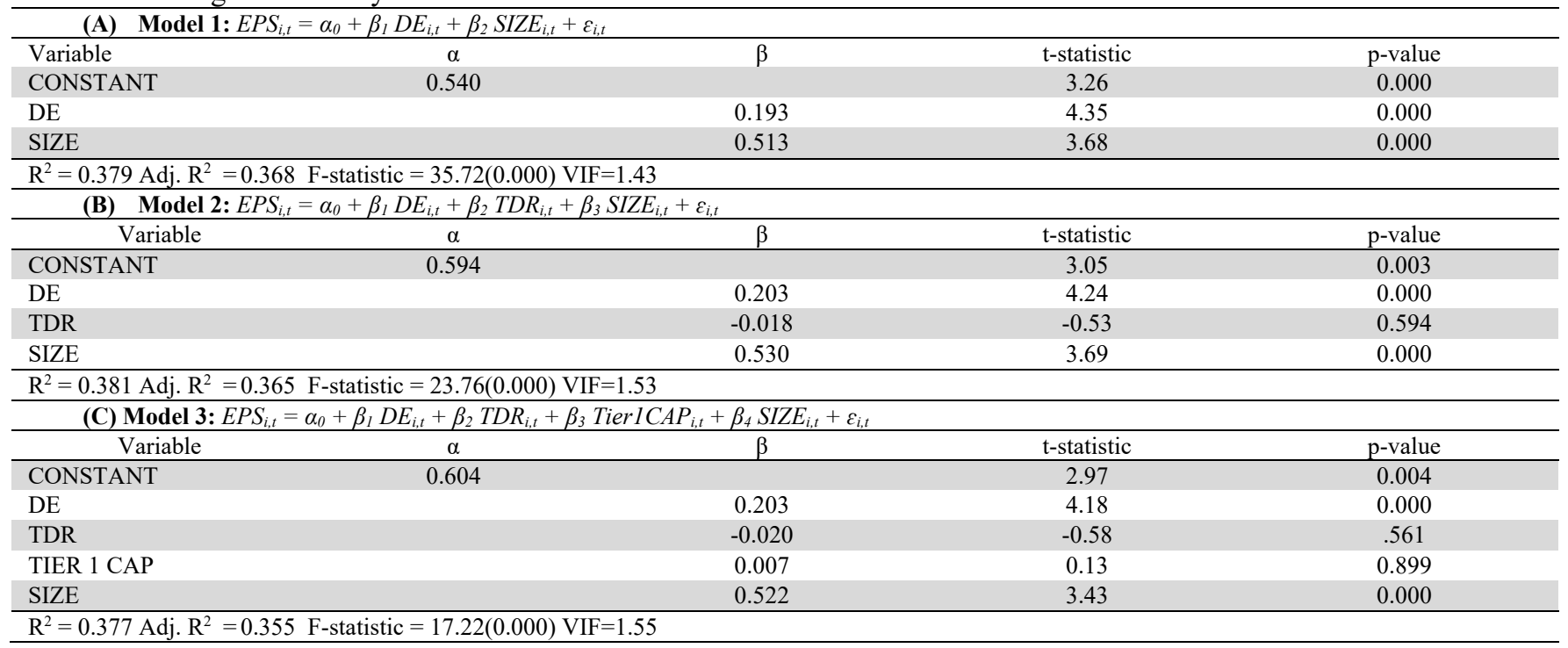

We report the results of pooled regression in this subsection estimated under different models. Table 5 reports the results of Models 4,5 and 6 where ROA is a predictable variable. The result shows that the unpredictable variable of leverage, DE is positive and significant at the $1 \%$ level of significance in model 4 , while it is positive and significant at the $10 \%$ level of significance in models 5 and 6. Similarly, the control variable SIZE is also positive and significant at the $1 \%$ level of significance in models 4 and 6 , while it is positive and significant at the 5\% level of significance in model 5.

\section{Table 5}

The results of the regression analysis

\begin{tabular}{|c|c|c|c|c|}
\hline \multicolumn{5}{|c|}{ (A) Model 4: $R O A_{i, t}=\alpha_{0}+\beta_{1} D E_{i, t}+\beta_{2} S I Z E_{i, t}+\varepsilon_{i, t}$} \\
\hline Variable & $\alpha$ & $\beta$ & t-statistic & $\mathrm{p}$-value \\
\hline CONSTANT & 0.664 & & 5.18 & 0.000 \\
\hline $\mathrm{DE}$ & & 0.095 & 2.78 & 0.006 \\
\hline SIZE & & 0.272 & 2.52 & 0.013 \\
\hline \multicolumn{5}{|c|}{$\mathrm{R}^{2}=0.209$ Adj. $\mathrm{R}^{2}=0.196$ F-statistic $=15.52(0.000) \mathrm{VIF}=1.43$} \\
\hline \multicolumn{5}{|c|}{ (B) Model 5: $R O A_{i, t}=\alpha_{0}+\beta_{1} D E_{i, t}+\beta_{2} T D R_{i, t}+\beta_{3} S I Z E_{i, t}+\varepsilon_{i, t}$} \\
\hline Variable & $\alpha$ & $\beta$ & t-statistic & $\mathrm{p}$-value \\
\hline CONSTANT & 0.488 & & 3.31 & 0.001 \\
\hline $\mathrm{DE}$ & & 0.065 & 1.79 & 0.076 \\
\hline TDR & & 0.059 & 2.30 & 0.023 \\
\hline SIZE & & 0.215 & 1.98 & 0.050 \\
\hline \multicolumn{5}{|c|}{$\mathrm{R}^{2}=0.244$ Adj. $\mathrm{R}^{2}=0.223$ F-statistic $=12.49(0.000) \mathrm{VIF}=1.53$} \\
\hline \multicolumn{5}{|c|}{ (C) Model 6: $R O A_{i, t}=\alpha_{0}+\beta_{1} D E_{i, t}+\beta_{2} T D R_{i, t}+\beta_{3}$ TierlCAP $P_{i, t}+\beta_{4} S I Z E_{i, t}+\varepsilon_{i, t}$} \\
\hline Variable & $\alpha$ & $\beta$ & t-statistic & p-value \\
\hline CONSTANT & 0.438 & & 2.88 & 0.005 \\
\hline DE & & 0.061 & 1.69 & 0.093 \\
\hline TDR & & 0.046 & 1.77 & 0.079 \\
\hline TIER 1 CAP & & 0.074 & 1.91 & 0.058 \\
\hline SIZE & & 0.145 & 2.88 & 0.005 \\
\hline
\end{tabular}


Further, the unpredictable variable TDR in model 5 is positive and significant at the 5\% and 10\% level of significance in models 5 and 6. Moreover, the variable of capital, Tier 1 CAP in model 3 is positive and significant at the $10 \%$ level of significance. The adjusted $\mathrm{R}^{2}$ of models 4,5 and 6 is $0.20,0.22$ and 0.23 , which shows that $22 \%$ of the variation in ROA on an average is explained by different unpredictable variables in different models. Furthermore, the F-statistic of all the models is significant at the $1 \%$ level of significance showing fitness of the model, and there is no multicollinearity among the unpredictable variables as the VIF is less than 2. Table 6 reports the results of Models 7,8 and 9 where ROE is the predictable variable. The result shows that the unpredictable variable of leverage, DE is positive and significant at the $1 \%$ level of significance in all the three models. Similarly, the control variable SIZE is also positive and significant at the $1 \%$ level of significance in model 7, while it is positive and significant at the 5\% level of significance in models 8 and 9 . Further, the unpredictable variable TDR in model 2 is negative but insignificant in models 8 and 9. Moreover, the variable of capital, Tier 1 CAP in model 9 is positive and significant at the $1 \%$ level of significance. The adjusted $\mathrm{R}^{2}$ of models 7,8 and 9 is $0.39,0.38$ and 0.41 , which shows that $39.33 \%$ of the variation in ROE on an average is explained by different unpredictable variables in different models. Furthermore, the F-statistic of all the models is significant at the $1 \%$ level of significance showing fitness of the model, and there is no multicollinearity among the unpredictable variables as the VIF is less than 2.

Table 6

The results of the regression analysis

\begin{tabular}{|c|c|c|c|c|}
\hline \multicolumn{5}{|c|}{ (A) Model 7: $R O E_{i, t}=\alpha_{0}+\beta_{1} D E_{i, t}+\beta_{2} S I Z E_{i, t}+\varepsilon_{i, t}$} \\
\hline Variable & $\alpha$ & $\beta$ & t-statistic & p-value \\
\hline CONSTANT & 0.184 & & 2.27 & 0.025 \\
\hline DE & & 0.110 & 5.07 & 0.000 \\
\hline SIZE & & 0.216 & 3.17 & 0.000 \\
\hline \multicolumn{5}{|c|}{$\mathrm{R}^{2}=0.395$ Adj. $\mathrm{R}^{2}=0.385$ F-statistic $=38.18(0.000) \mathrm{VIF}=1.43$} \\
\hline \multicolumn{5}{|c|}{ (B) Model 8: $R O E_{i, t}=\alpha_{0}+\beta_{1} D E_{i, t}+\beta_{2} T D R_{i, t}+\beta_{3} S I Z E_{i, t}+\varepsilon_{i, t}$} \\
\hline Variable & $\alpha$ & $\beta$ & t-statistic & $\mathrm{p}$-value \\
\hline CONSTANT & 0.205 & & 2.16 & 0.033 \\
\hline DE & & 0.114 & 4.87 & 0.000 \\
\hline TDR & & -0.007 & -0.44 & 0.661 \\
\hline SIZE & & 0.223 & 2.16 & 0.033 \\
\hline \multicolumn{5}{|c|}{$\mathrm{R}^{2}=0.396$ Adj. $\mathrm{R}^{2}=0.380$ F-statistic $=25.34(0.000) \mathrm{VIF}=1.53$} \\
\hline \multicolumn{5}{|c|}{ (C) Model 9: $R O E_{i, t}=\alpha_{0}+\beta_{1} D E_{i, t}+\beta_{2} T D R_{i, t}+\beta_{3}$ TierlCAP $P_{i, t}+\beta_{4} S I Z E_{i, t}+\varepsilon_{i, t}$} \\
\hline Variable & $\alpha$ & $\beta$ & t-statistic & p-value \\
\hline CONSTANT & 0.151 & & 1.57 & 0.119 \\
\hline DE & & 0.110 & 4.83 & 0.000 \\
\hline TDR & & -0.019 & -1.13 & 0.262 \\
\hline TIER 1 CAP & & 0.071 & 2.88 & 0.005 \\
\hline SIZE & & 0.158 & 2.20 & 0.030 \\
\hline $\mathrm{R}^{2}=0.434$ Adj. $\mathrm{R}^{2}=$ & 21.82 & & & \\
\hline
\end{tabular}

\section{Discussion}

The association between the financial performance variables, such as EPS, ROA and ROE and Debt-Equity is positive in all the models; TDR is negative but insignificant with the EPS and ROE, and significantly positive with the ROA; Tier 1 capital is positive and significant with ROA and ROE, and insignificant with the EPS. The positive impact of debt on profitability shows that, the use of debt in the capital structure of a firm enhances its performance as suggested by Champion (1999), and a study by Abor, 2005; Ahmed et al. 2012)) reported a positive association between short-term debt and profitability variables, such as ROA and ROE in South African and Malaysian firms. This shows that the greater the debt, the higher the banks outreach by extracting higher premiums from the advanced loans. This extraction results in cash inflow and increases profitability of banks to service the debt. Moreover, this greater outreach gives banks scope to reduce their operation cost (Bos and Fetherston, 1993; Kyereboah, 2007; Tripathy \& Shaik, 2020). Further, the positive association between the performance variables and banks' leverage might be due the low equity ratios as they increase the efficiency of firms by reducing the agency costs as per the efficiency risk hypothesis (Fatoki and Olweny, 2017). The other reason for the positive association is that the banks hold debt for a short-term, such as customer deposits, deposits of other banks, etc. The short-term debt is attributed as cheaper, hence enhancing the performance of banks. Therefore, the results reported by the current study are in line with other studies (e.g. Abor, 2005; Wang, 2010; Ahmed et al. 2012; Fatoki and Olweny, 2017; Hadlock and James, 2002; Ramadan et al. 2011; Nyawira et al. 2017) and in contrast to the results of some others (e.g. Cheng, 2009; Chen et al. 2008; Krivogorsky et al. 2009; Ebaid, 2009).

\section{Conclusion}

The concept of leverage and capital plays a significant role in the financing decisions of a firm. These two financial factors in turn affect the financial performance of a firm in different ways. The optimal mix of leverage and capital shall enhance the value 
of a firm as quoted by different authors in the past. Moreover, these two financial factors are considered important in terms of banking firms, since these firms are operated and regulated by the Basel committee norms. The debt and capital of banks is assumed as significant for their stability and growth. The banking sector of Saudi Arabia has a larger stake in building the Kingdoms' Vision 2030. We therefore consider being important to study the effect of leverage and capital on the financial performance of Saudi Arabian banks. Concerning this, we selected five banks based on their growth and performance examining the impact of leverage and capital on their financial performance during the period 2014-2019 by estimating a pooled regression. We found a positive association between the financial performance variables and Debt-Equity, while TDR is negatively related with EPS and ROE, and positively related with ROA, and Tier 1 capital is positively related with ROA and ROE and negatively related with EPS. The important reason for positive association between the financial performance variables and leverage and capital is that the banks hold debt for a short-term, such as customer deposits, deposits of other banks, etc. The study can be extended by sorting the leverage into short-term debt and long-term debt, including some control variables, such as Gross Domestic Product (GDP) and inflation into the model.

\section{References}

ABUBAKAR, A. (2017). Financial leverage and financial performance of quoted industrial goods firms in Nigeria. $K A S U$ Journal of Management Science, 8(2), 89-108.

Adesina, J. B., Nwidobie, B. M., \& Adesina, O. O. (2015). Capital structure and financial performance in Nigeria. International Journal of Business and Social Research, 5(2), 21-31. DOI:10.18533/IJBSR.V5I2.710

Afolabi, A., Olabisi, J., Kajola, S. O., \& Asaolu, T. O. (2019). Does leverage affect the financial performance of Nigerian firms?. Journal of Economics \& Management, 37, 5-22. DOI: 10.22367/jem.2019.37.01

Ahmad, N., Salman, A., \& Shamsi, A. (2015). Impact of financial leverage on firms' profitability: An investigation from cement sector of Pakistan. Research Journal of Finance and Accounting, 6(7), 2222-1697

Ahmad, R. (2016). A study of relationship between liquidity and profitability of standard charterd bank Pakistan: Analysis of financial statement approach. Global Journal of Management and Business Research, 6(10).

Akhtar, S, Jave, B., Maryam, A., \& Sadia, H. (2012), Relationship between financial leverage and financial performance: Evidence form fuel \& Energy Sector of Pakistan. European Journal of Business and Management, 4(11).

Ali, M. (2020). Impact of leverage on financial performance (Evidence from Pakistan food and fertilizer sector). Journal of Critical Reviews, 7(13), 447-456. doi: 10.31838/jcr.07.13.79

Almajali, A. Y., Alamro, S. A., \& Al-Soub, Y. Z. (2012). Factors affecting the financial performance of Jordanian insurance companies listed at Amman Stock Exchange. Journal of Management Research, 4(2), 266.

Al-Tally, H. A. (2014). An investigation of the effect of financial leverage on firm financial performance in Saudi Arabia's public listed companies (Doctoral dissertation, Victoria University).

Bagais, O., \& Aljaaidi, K. (2020). Corporate governance attributes and firm performance in Saudi Arabia. Accounting, 6(6), 923-930. doi: 10.5267/j.ac.2020.8.005

Barakat, A. (2014). The impact of financial structure, financial leverage and profitability on industrial companies shares value (applied study on a sample of Saudi industrial companies). Research Journal of Finance and Accounting, 5(1), 55-66.

Bauer, P. (2004). Determinants of capital structure: empirical evidence from Czech. Journal of Economics and Finance, 54, 121.

Mangalam, S., \& Govindasamy, P. (2010). Leverage- An Analysis and its Impact On Profitability With Reference to Selected Cement Companies in India. European Journal of Economics, Finance and Administrative Sciences, 27, 53-65

Dalci, I. (2018). Impact of financial leverage on profitability of listed manufacturing firms in China. Pacific Accounting Review. 30(12), 410-432. DOI: 10.1108/PAR-01-2018-0008

Daryanto, W., Samidi, S., \& Siregar, D. (2018). The impact of financial liquidity and leverage on financial performance: Evidence from property and real estate enterprises in Indonesia. Management Science Letters, 8(12), 1345-1352. DOI: $10.5267 /$ j.msl.2018.9.005

Ebiringa, O. T., \& Ezeji, E. C. (2012). Analysis of effect of financing leverage on bank performance: Evidence from Nigeria. Journal of Public Administration and Governance, 2(4), 178-187. DOI: 10.5296/jpag.v2i4.3036

Gill, A. S., Mand, H. S., Sharma, S. P., \& Mathur, N. (2012). Factors that influence financial leverage of small business firms in India. International Journal of Economics and Finance, 4(3), 33-45. DOI: 10.5539/ijef.v4n3p33

Gweyi, M. O., \& Karanja, J. (2014). Effect of financial leverage on financial performance of deposit taking savings and credit co-operative in Kenya. International Journal of Academic Research in Accounting, Finance and Management Studies, 4(2), $176-184$.

Ho, S. J., \& Hsu, S. C. (2010). Leverage, performance and capital adequacy ratio in Taiwan's banking industry. Japan and the World Economy, 22(4), 264-272. https://doi.org/10.1016/j.japwor.2010.06.007

Ilyukhin, E. (2015). The impact of financial leverage on firm performance: Evidence from Russia. Корпоративные финансы, 9(2), 24-36. DOI: $10.17323 /$ j.jcfr.2073-0438.9.2.2015.24-36

Javed, Z. H., Rao, H. H., Akram, B., \& Nazir, M. F. (2015). Effect of financial leverage on performance of the firms: Empirical evidence from Pakistan. SPOUDAI-Journal of Economics and Business, 65(1-2), 87-95. 
John, A. O., Odutola, O. J., \& Olurotimi, O. E. (2015). Effect of financial leverage on corporate performance: Evidence from Nigerian hospitality industry. Grawford Journal of Business \& Social Science, 8(11), 15-21.

Keown, A.J., Martin, J.D., Petty, J.W., \& Scot, D.F. (2003). Foundation of Finance. Person Education Limited, New Jersey.

Kumar, D. M. (2014). An Empirical Study on Relationship between Leverage and Profitability in Bata India Limited. International Journal of Advance Research in Computer Science and Management Studies, 2(5), 1-9.

Morellec, E. (2004). Can managerial discretion explain observed leverage ratios?. The Review of Financial Studies, 17(1), 257294. https://doi.org/10.1093/rfs/hhg036

Mukras, M. S. (2015). Financial leverage and performance of listed firms in a frontier market: Panel evidence from Kenya. European Scientific Journal, 11(7), 534-550. DOI:10.19044/ESJ.2015.V11N7P\%P

Obradovich, J., \& Gill, A. (2013). The impact of corporate governance and financial leverage on the value of American firms. 91(1), 1-14.

Pratheepkanth, P. (2011). Capital structure and financial performance: evidence from selected business companies in Colombo stock exchange Sri Lanka. Researchers World, 2(2), 171-183.

Shaik, A.R., \& Sharma, R.B. (2020). Cash flows and financial performance in the industrial sector of Saudi Arabia: With special reference to Insurance and Manufacturing Sectors. Investment Management and Financial Innovations, 17(4), 76-84. doi:10.21511/imfi.17(4).2020.07

Singh, A. K., \& Bansal, P. (2016). Impact Of Financial Leverage On Firm's Performance And Valuation: A Panel Data Analysis. Indian Journal of Accounting, 2, 73-80.

Tripathy, S., \& Shaik, A.R. (2020). Leverage and firm performance: Empirical evidence from Indian food processing industry. Management Science Letters, 10(6), 1233-1240. doi: 10.5267/j.msl.2019.11.035

Ujah, U., \& Brusa, O. (2013). The Effect of Financial Leverage and Cash Flow Volatility on Earnings Management. Texas A \& M International University.

Wabwile, E. S., Chitiavi, M. S., Alala, O. B., Douglas, M., Khoo, V., Obeid, M., \& Islam, M. (2014). Financial Leverage and performance variance among banks: evidence of tier 1 commercial banks listed on Nairobi Security Exchange Kenya. International Journal of Business and Management Invention, 3(4), 01-13.

Zeitun, R., \& Saleh, A. S. (2015). Dynamic performance, financial leverage and financial crisis: evidence from GCC countries. EuroMed Journal of Business. 10(2), 147-162. DOI 10.1108/EMJB-08-2014-0022

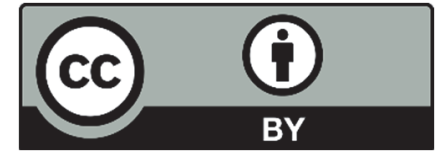

(C) 2021 by the authors; licensee Growing Science, Canada. This is an open access article distributed under the terms and conditions of the Creative Commons Attribution (CC-BY) license (http://creativecommons.org/licenses/by/4.0/). 